\title{
Utilization of Artificial Intelligence Model for Mapping Information and Communication Technology in Education Diah Wulandari ${ }^{a, *}$ and Mohamad Adning ${ }^{b}$
}

\author{
${ }^{a}$ Administrator of Network and Information System, Center of ICT for Education and Culture \\ ${ }^{\mathrm{b}}$ Fungsional Technology of Learning Staff, Center of ICT for Education and Culture \\ Ministry of Education and Culture, Republic of Indonesia
}

\begin{abstract}
This article describe an utilization Artificial Intelligence model using Self-Organizing Map (SOM). Research start in 2015 and a total sample 50 schools starting from junior high school until senior high school around Java Island. The result showed that SOM Model improved to mapping school in utilization Information and Communication Technology (ICT). Moreover, this research adopts the indicator from UNESCO Institute for statistic (UIS). SOM model able to mapping 50 school with 26 characters become 6 cluster which a curation quantization error 1,3831 and topographical error $0 \%$. There are 6 main characters such as utilization television for learning, ICT competence for teacher, ICT support service for education, utilization facility ICT in school from students, students participation for learning based on ICT and basic computer skill. This article will be helpful for Canter of ICT for Education Ministry of Education and Culture Republic Indonesia to make many model based on characteristic ICT.
\end{abstract}

Keywords: Utilization of ICT for Education, Self-Organizing Map (SOM)

\section{Background}

Information and communication technology (ICT) is technology use in information and communication based on electronics who used to take, collect, process, storage, spread out and presentation of data, information and content (kemendikbud, 2013). ICT for education has significant play a role to spread out access, reduce the cost and improve the quality of education (UIS, 2014). As a teacher tools, ICT has been proved to increase the concentration of students by making learning more fun and improve learning outcomes and conduct of students (Hussain,at al., 2011). Teacher use ICT skill to provide learning material with each content, finding the sources and making the presentation used by the digital media, as a result, the learning process more fun for students (Umar and Yusof, 2014).

Lifelong learning regarded as one of the success keys for education by developing the potential and creativity from individual students and teachers (active learning) which there are supported by instruction involving a group of students to get an academic goal (collaboration learning) (Pinhero and Simoes, 2012). Collaboration activity can form a social skill, for instance, critical thinking and respect each other when the contending with another member of the group in digital media. In addition, it is also accessible to storage learning material. On the other hand, ICT helps the teacher to understand students of material through the task of the groups with collaborative learning and helps the teacher to evaluate based on students' activity where each group has history class record.

The measurement of ICT for education needs to be done because of high demand for the data analysis of ICT for education as a primary information statistical to support the policy of ICT for education (UIS, 2014). ICT policy is using to provide service ICT such as data, information, content, application and infrastructures and human development (Kemendikbud,2013). The indicator for measurement progress of ICT refers to UNESCO Institute for Statistics (UIS) (ITU ,2010) were elaborated in Guide to Measuring Information and Communication Technologies (ICT) in Education (UIS, 2009). This indicator has been adopted by many researchers such as analysis factor affect a composite index of information technology on elementary school and secondary school by uses the method Hierarchy Analytic Processes (AHP) (Aoki et ac.,2013) and research about the comparison a statistical aggregate data analysis school every country where describe the integrating ICT condition and ereading in ASIA.

Aims of this article are to make a system based on Selforganizing Map (SOM) to map implementation ICT for education in a school that the stakeholder can get information about the condition implementation ICT in school. Ministry Education and Culture of Republic Indonesia through the center of Information Technology and Communication (Pustekkom) has been developed many models based on ICT. In 2017, Pustekkom has chosen 100 a school who will use utilisation ICT for education (Pustekkom, 2017). Normally, the process determination of school further investigated previously carried out by cooperation with the government of the region.

SOM is an artificial neural network trained to produce presentation maps with two dimensions from data sample with high dimension. An algorithm SOM has applied in many field subject research for instance in geology ( Mojarab, et al. , 2014), biomedical (Schilithz,et al., 2014; Matharage,et al., 2011), economic and business (Iturriaga Sanz, 2013; Azadnia, et al., 2012), and environment (Juntunen,et al., 2013). In ICT, SOM has been proved to make potential group ICT at South Sulawesi (Amin, 2012), 
and a map progress ICT for education in Jakarta (Arti, et al. 2010).

Grouping by analysis on the data not ideal or "messy data" uses the method SOM produce cluster with the higher accuracy than a hierarchy method (Magiameli, et.al., 1996) or other traditional methods such as K-means (Budayan,et al., 2009) based on a comparison performance of a trawl SOM and centroid method used by a hierarchy and another traditional method. SOM uses unsupervised competitive learning to determine "winning neurons", the weighting of vector update to get the best matching event unit (BMU). BMU is nodes with the nearest vector weight with vector input. Thus the mapping is not changed characteristic of the data (Dragomir, et al., 2014).

On a hierarchy method, cluster with smallest distance centroid merged into one cluster on the repetition after next up have one cluster, but for data have infinite high dimensional and containing a noise level, a hierarchy methods have a great big mistake to merging cluster and then accumulated on iteration next assignment and do not could be repeated (Magiameli,et al.,1996 ). Moreover with K-means method, choosing location centroid by counting average all value in each feature then average distance between data and centroid-centroid cluster used to allocate data into a cluster based on ratios the shortest distance (Budayan, et.al., 2009). The displacement can change characteristic natural shape data (Agusta,Y., 2007). However, there are advantages of SOM method like a visualisation ability to give information about cluster struktur in the form of $U$ matrix where presented the relationship between the variables and estimated values of one variable to all neurons. U matric with high-value show cluster border and lower value in the same area show that cluster owns self (Budayan, et al., 2009). As a result of this, a method SOM that took place had been selected based on as a method of analysis support for new groupings by globe are using to map how conditions the application of ICT for education development at the based on the characteristics of the schools.

\section{Literature Review}

\subsection{ICT indicators for education}

They are five main indicators such as infrastructure and access, access and utilization ICT for individual and household, access and utilization ICT for business, sector ICT and trading, access and utilization ICT for education. Institute for Statistics (UIS) has been developed access indicator and utilization ICT for education (ITU, 2010). UIS used framework where that formula based on a question policy such as commitment policies, infrastructure, teacher developed, curriculum, utilization, participation, skill, output and outcome. The indicators used to monitor the development ICT for Education globally with emphasis on the role of a major school as an object of data collection, and to monitor the access, utilization, and goal of ICT for education.

ICT indicator was developed by UIS can use in any level such as international level, national level, sub-national, even though at school. At the international and national level, that indicator used for monitor and supporting policy formula and taking a decision. However, sub-national and school indicator has used for compare ICT infrastructure, access, utilization and goal of learning. The main principal choose the indicators is policy relevance, the reliable data collection, minimize the burden of the data collection and an international comparison (UIS, 2019). The evolution information needs every national policy implementation section with change the rate penetration of ICT in the educational system illustrated in figure 1

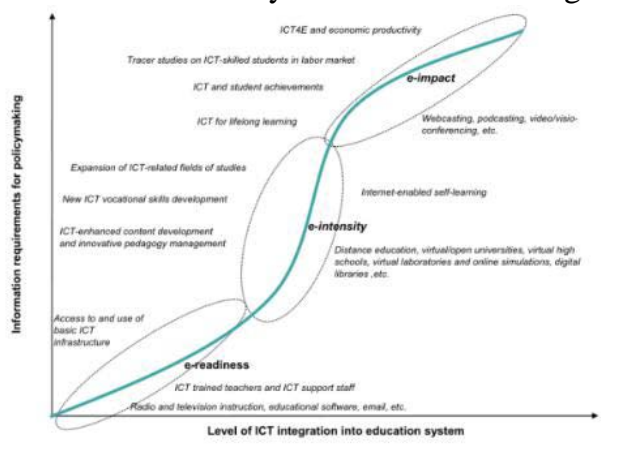

Page | 56

Figure 1

\subsection{Self-Organizing Map (SOM)}

SOM is artificial neural network trained to produce presentation maps two dimensions of data sample infinite dimensional high. The standard Algorithm SOM use unsupervised training process, output target unspecified but they are using the wighting of random corresponding with vector input (Dragomir,et al., 2014). How to work SOM essentially is "winner Model” whereby any input data must choose look at in accordance with vector input, then the selected model and neighbors model in the grid renewed to get best matching unit (BMU) (Kohonen, 2013). This model choose by calculate the distance eulidean between each weight vector node and vector input in all node. The node with the nearest vector with input vector choose as BMU (Dragomir, et al. 2014). In figure 2, input $\mathrm{x}$ released into a model $\mathrm{Mi}$, while $\mathrm{Mc}$ is BMU from $\mathrm{X}$, so that all model is in one neighbourhood from Mc (on circles) is a model is in line with compared with model out of the circles. (kohonen, 2013)

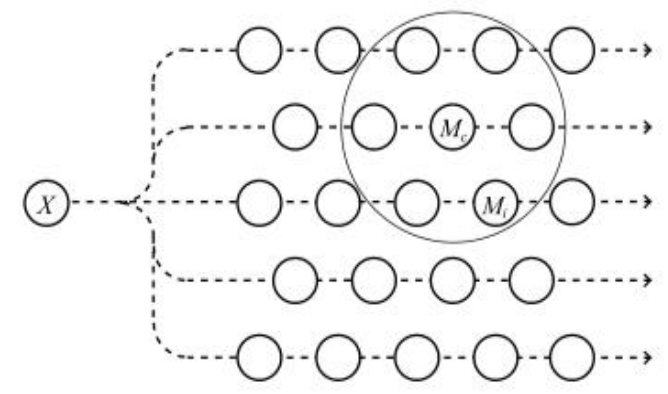

Figure 2. Ilustrasi Self-organizing Map

This is the step of SOM algorithms (Dragomir, et al., 2014)

1. Initialization the number of unit $\mathrm{C}$ class, prototype $\mathrm{W}_{\mathrm{i}}$, learning rate $\mathrm{l}_{\mathrm{r}}(\mathrm{t})$, neighbourhoods $\mathrm{N}_{\mathrm{i}}(\mathrm{t}), \mathrm{i}=1$...C, maximum iteration count $\mathrm{T}_{\max }$ and accuracy $(\varepsilon)$

2. Enter a new pattern $X_{p}$ to nettworking

3. Decide the winner a unit of class $j$, closest to pattern $\mathrm{X}_{\mathrm{p}}$ : $=\min ()=\min (\|()-\|), \forall=1 \ldots(1)(2.1)$ 
4. Renew the prototype of a class a unit of the winner and class unit in neighbourhood $\mathrm{N}_{\mathrm{j}}(\mathrm{t})$ :

$(+1)=()+()[-()], \forall \in()(2.2)$

5. renew learning rate $\operatorname{lr}(\mathrm{t}+1)$ dan neighbourhood $\mathrm{Ni}(\mathrm{t}+1), \mathrm{i}=1 \ldots \mathrm{C}$

6. repeat step 2-5 until there is no prototypes with changes in the value of errore (consecutive) two time consecutive) or maximums iteration $\mathrm{T}_{\max }$ get result

\subsection{Davies-Bouldin Index}

Davies-Bouldin index use to identify level of compactness and separability from cluster set. The smaller of index value shows the better clustering level. Davies- Bouldin index is identified as follow:

with c declare cluster number, $i, j$ represent cluster label, $d\left(X_{i}\right)$ and $d\left(X_{j}\right)$ are all cluster sample $i$ and $j$ in each centroid, pada masing-masing centroid, dan $\mathrm{d}\left(\mathrm{C}_{\mathrm{i}}, \mathrm{C}_{\mathrm{j}}\right)$ are distance between centroid (Rendón dkk., 2011).

\subsection{Quantization Error (qe)}

qe used to evaluate properness SOM mapping result by measure average distance between BMU and every data vector. The smaller qe value shows data near with BMU's neuron-

with $N$ declare number of data vector, $w \mathrm{~km}$ is BMU that appropriate with $x_{m}$ vector data (Schilithz dkk., 2014).

\subsection{Topographical Error (te)}

te is used to measure sample percentage that have not close BMU

With $N$ represent vector data number and m represent BMU number. $u\left(x_{m}\right)$ will have value 1 if the first and second BMU are contiguous, otherwise valued 0 . The smaller te value represent stable topology of SOM mapping result (Schilithz, dkk., 2014).

2.6. School Model develop by Center of ICT for Education and Culture (Pustekkom)

Pustekkom becomes the centre of applying the theory and practice of technology education. The main of function Pustekkom is to solve education with technology. Supporting by 307 staff with any skill and capability. As a result, Pustekkom produces any prototype model learning based on ICT, and media to support the national education system. Many media such as Education television, education portal, education radio, mobile education have developed Pustekkom. In other words, Pustekkom is the centre who would serve the community to increase access to education services through utilisation ICT in Indonesia (Pustekkom, 2017).

Based on track record of pustekkom in 2017,100 schools has been applied prototype model innovative by pustekkom (Pustekkom, 2015). Another prototype around 49 school has used learning resource model and 164 school in the front line, remote area used ICT model by Pustekkom. Page | Furthermore, 2000 school has been connected by internet an 57 online networking, and 2.756 schools have utilised education television and radio. in addition, 5.055 teachers have been trained by Pustekkom for developing and utilisation ICT for education (Pustekkom, 2015).

Analysis and designing protype model had developt by people who has instructional design in Pustekkom around 84 staff. That people has capability to designing protype using ADDIE model (Pustekkom, 2015). However, choosing a location for applying model by cooperation with the local government. There were no standard methods of how to choose location and cluster for school using ICT for education. As a result, several obstacles will emerge in the implementation.

\section{Metodologi}

The measurement of ICT for education in school adopted from ICT developed by UIS, where the adopted to measure ICT at school (table 1). The measurement result is 26 indicator Then translated in the form of a question to capture 43 data. They used data tabulation to calculate every value indicators and produce numbers data ICT school as an input system. Processing data ICT schools with pre-process data using algorithms Principal component analysis (PCA). It is used to reduce 26 dimensions to 5 dimensions without losing the characteristic (Diah Wulandari, et.all, 2015). To get a good structure, data reduction normalised. The result of this data then used to train SOM networking.

Tabel 1. ICT Indicator for education in school as a result of adaptation from UIS Indicators 2009

\begin{tabular}{ll}
\hline Curriculum Commitment \\
\hline ED10 & $\begin{array}{l}\text { The average number of hours per week the use ICT in the } \\
\text { class based on per subject (mathematics, sciene, computer } \\
\text { basic, language, art) }\end{array}$ \\
\hline ED11 & $\begin{array}{l}\text { The average number of hours per week the use ICT in } \\
\text { class based on curriculum } \\
\text { a. computer exercise - based on education software } \\
\text { b. computer exercise - use internet } \\
\end{array}$ \\
$\begin{array}{ll}\text { c. Radio (learn by radio interaction) } \\
\text { d. Televisi }\end{array}$ \\
\hline Infrastructures \\
\hline EDR1 & Electric resource at school \\
\hline ED2 & Utilization radio for a learning process \\
\hline ED3 & Ttilization TV for a learning process \\
\hline ED4 & The ratio of learner-to-computer at school with the tools for \\
& learning lessons computer \\
\hline ED4 & The ratio of learner-to-computer \\
\hline ED5 & The availability of internet access school (access type) \\
\hline ED25 & The ratio of learner-to-computer with internet access \\
\hline ED29 & The proportion of the availability of computer for learning \\
\hline
\end{tabular}




\begin{tabular}{ll}
\hline ED30 & $\begin{array}{l}\text { The proportion of the availability of computer for } \\
\text { adminstration }\end{array}$ \\
\hline ED31 & The availability school website \\
\hline Teacher development \\
\hline ED8 & Teacher who have ICT qualification \\
\hline ED34 & The availability service for supporting ICT \\
\hline ED35 & $\begin{array}{l}\text { The proportion of teacher who was training with distance } \\
\text { learning program }\end{array}$ \\
\hline ED36 & The proportion of teacher teach computer skill \\
\hline ED37 & The proportion of teacher teach using ICT facility \\
\hline ED38 & The proportion of expert teacher teach using ICT facility \\
\hline ED39 & The ratio teacher has computer skill \\
\hline ED40 & The ratio teacher has to use ICT for teaching \\
\hline Utilization & \begin{tabular}{l} 
The proportion of students has internet access at school \\
\hline ED6
\end{tabular} \\
\hline ED41 & $\begin{array}{l}\text { The proportion of students who have the right to use } \\
\text { computer laboratories at a school to learning }\end{array}$ \\
\hline Students participation \\
\hline ED44 & $\begin{array}{l}\text { The proportion of students enrolled in the classroom with } \\
\text { based learning ICT }\end{array}$ \\
\hline ED45 & $\begin{array}{l}\text { The proportion of students who enrolled in a classroom } \\
\text { where skill computer basic taught }\end{array}$ \\
\hline ED48 & $\begin{array}{l}\text { The proportion of students whom the successful } \\
\text { completion of a lesson computers base at the end of an } \\
\text { academic year }\end{array}$ \\
\hline
\end{tabular}

Tabel 2. Principal Component Analysis Result in each variable domain (Diah Wulandari, dkk., 2016)

\begin{tabular}{lccc}
\hline The most influence variable & $\begin{array}{l}\text { The highest } \\
\text { Eigenvalue }\end{array}$ & $\begin{array}{c}\text { \% } \\
\text { commulative }\end{array}$ & $\begin{array}{c}\text { Correlation } \\
\text { value }\end{array}$ \\
\hline $\begin{array}{l}\text { Curriculum Commitment: } \\
\text { ED11 The average number of } \\
\text { hours per week the use ICT in } \\
\text { class based on curriculum }\end{array}$ & 13,04 & 87,70 & 0,983 \\
\hline $\begin{array}{l}\text { Infrastructures : } \\
\text { ED31 The availability school } \\
\text { website }\end{array}$ & $3,69 \mathrm{E}+10$ & 99,99 & 1 \\
\hline $\begin{array}{l}\text { Teacher development: } \\
\text { ED34 The availability service } \\
\text { for supporting ICT }\end{array}$ & $2,32 \mathrm{E}+15$ & 100 & \\
\hline $\begin{array}{l}\text { Utilization: } \\
\text { ED41 The proportion of } \\
\text { students who have the right to }\end{array}$ & & & \\
use computer laboratories at a \\
school to learning
\end{tabular}

Determine the total clusters of extremely important to ease in getting the resulting clustering good. It is important to determine the total cluster where they can lead to a good cluster. Moreover, to calculate the analysis cluster use index from Davies-Bouldin in repeated algorithms K-means. The best cluster will be chosen based on occur frequency as a result from analysis and point of index Davies-Bouldin. The best cluster use for the reference in analysis SOM clustering. There are training for net SOM with different total iterate to get the best cluster. Cluster with minor error will be chosen as the best cluster, and it is will visual in the dashboard which the show group in graphicDetermine the total clusters of extremely important to ease in getting the resulting clustering good. It is important to determine the total cluster where they can lead to a good cluster. Moreover, to calculate the analysis cluster use index from Davies-Bouldin in repeated algorithms K-means. The best cluster will be chosen based on occur frequency as a result from analysis and point of index Davies-Bouldin. The best cluster use for the reference in analysis SOM clustering. There are training for net SOM with different total iterate to get the best cluster. Cluster with minor error will be chosen as the best cluster, and it is will visual in the dashboard Page | 58 which the show group in graphic.

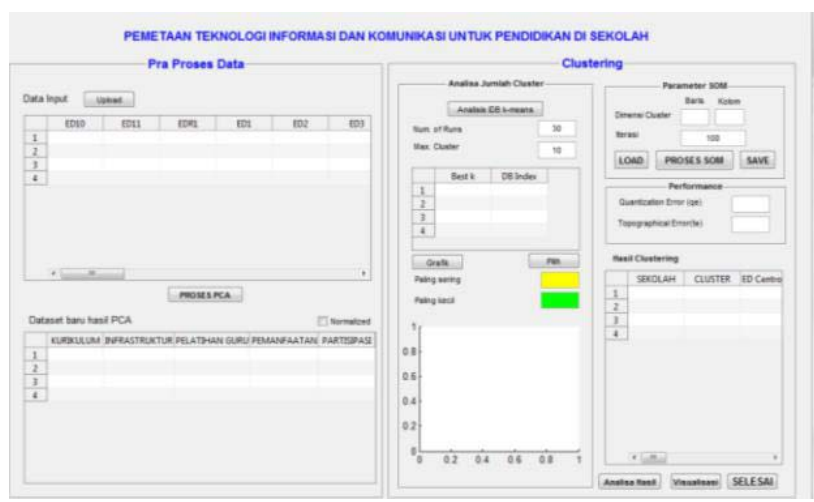

Figure 3. Information System Interface

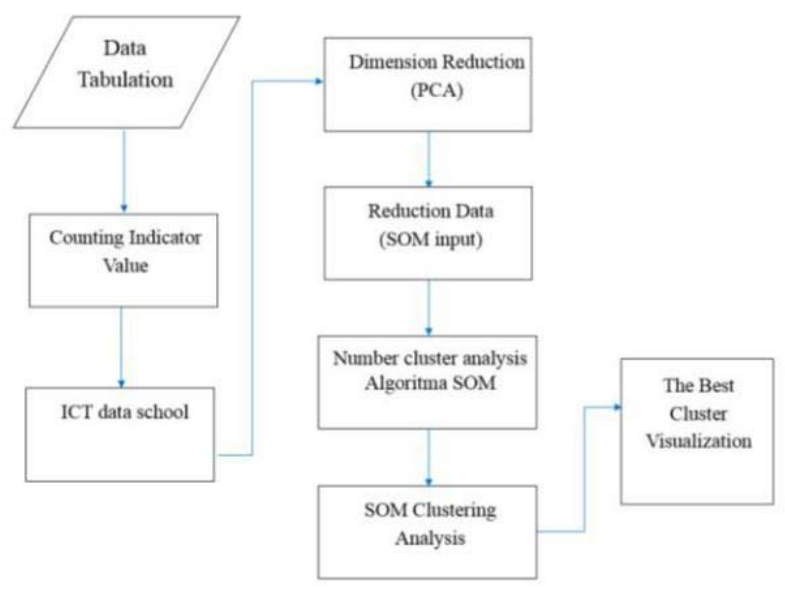

Figure 4. I-P-O Framework Model

\section{Result and Discuss}

\subsection{Cluster Number Determination Analysis}

Iteration using maximal cluster number $($ c_max $)=10$ with iteration number (num_run) $=100$. The result of $\mathrm{k}$ means analysis showed that the best number cluster with frequent arise is 2 (37 times), the smallest DB index 0.857 and the best cluster number with the smallest DB index is 6 (19 times), the smallest DB index 0.838. This result is used as SOM network training parameter.

\subsection{Clustering Result}

SOM network training have been done by iteration number 100 untul 500, dimension 2 and 6, random topology (rand_init), sequential algorithm. The trained SOM network is measured to evaluate result cluster quality. The best cluster quality was produced by the trained SOM network with number cluster 6 and iteration 
300. U-matrix on figure 5 describe hits number/cluster data and general correlation between cluster. The similarity or colour gradation represent strong correlation between cluster, the hexagonal size represent distance between neighbor unit. The gradation analysis shows that cluster with strong correlation are cluster 1 to cluster 2 dan 3, cluster 4 to cluster 5 . Otherwise cluster 6 didn't have correlative with the other cluster.

Based on clustering result, sample data each cluster then analyzed using significant test through each variable. Table 3 shows the resume of data variable in 6 group. The representation variable with significant statically ( $\mathrm{p}$-value

$<0,05)$ to distinguish the groups. There are five the main characteristic of what the different clusters. Firstly, utilisation of TV for learning, Secondly, the competence of ICT teachers (basic knowledge, training skill, and implementation use ICT). Thirdly, the availability of supporting the ICT. Fourth, the facilities ICT school for students (how to access the internet and computer laboratories). The last is the participation of students in the based learning of information technology and extra skill the basic computer.

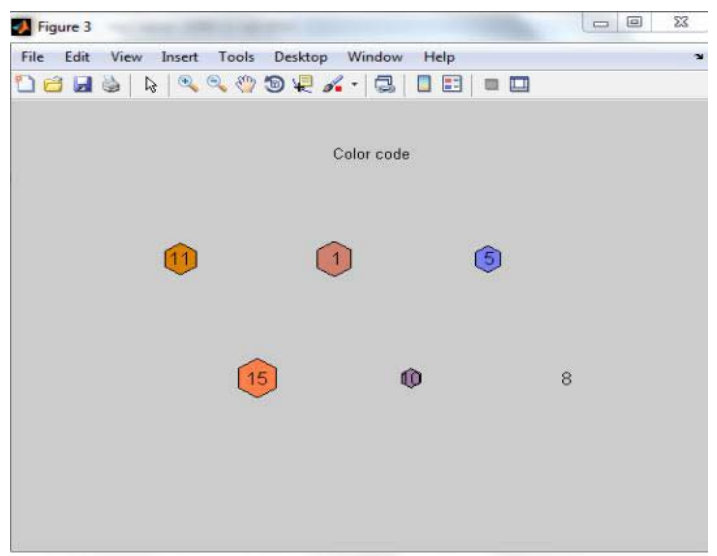

Figure 5. Level of Correlation Between Cluster in Colour Gradation

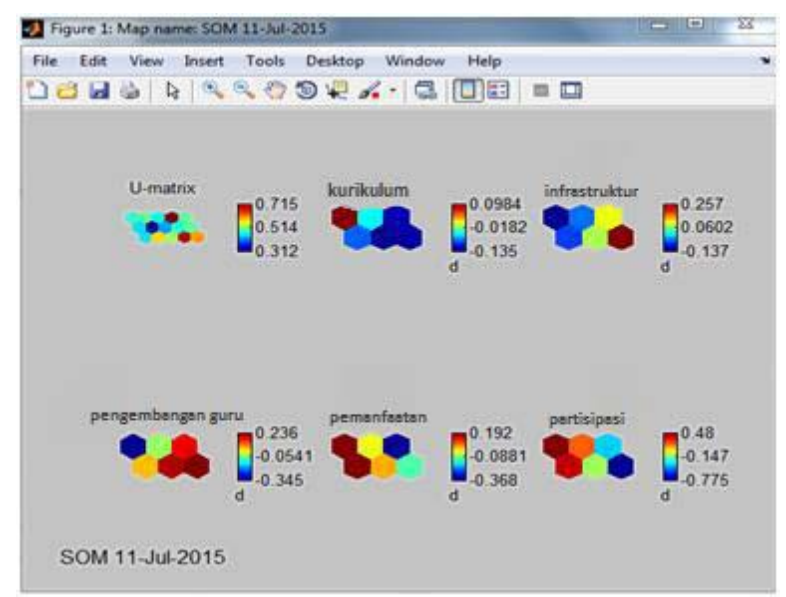

Figure 6. Variable Relationship Visualitation to Clusters

The first groups are consisting of 11 schools that the utilisation of television for learning with average as much as 2,27 a unit per school. In addition, the availability of funds or cost for services ICT is the biggest (> 90 million rupiah per years) if compared with other groups. The quality of teachers in ICT skill is very high with the proportion of teachers who have the competence of the base of ICT as much as $83,68 \%$. Around $74,9 \%$ the teachers are well trained using ICT, and $80,53 \%$ the teacher used ICT for a learning process. A higher proportion of students who use the internet for learning as much as $96,37 \%$ and overall the students used computer lab for study. The number of participants students who follow learning use ICT around $96,3 \%$ and class computer lab as much as $88,02 \%$. The second groups are consisting of 15 schools that the utilisation of television for learning with average as much as 4 a unit per school. In addition, the availability of funds or cost for services ICT is the lowest (> 12 million rupiah per years) if compared with other groups. The quality of teachers in ICT skill is higher with the proportion of teachers who have the competence of the base of ICT as much as 62,96 $\%$. Around $65,26 \%$ the teachers are well trained using ICT, and $74,88 \%$ the teacher used ICT for a learning process. Overall the students used the internet for learning and computer lab for study. The number of participants students who follow learning use ICT around 98,1\% and all students joint the class computer.

The second groups are consisting of 15 schools that the utilisation of television for learning with average as much as 4 a unit per school. In addition, the availability of funds or cost for services ICT is the lowest ( $>12$ million rupiah per years) if compared with other groups. The quality of teachers in ICT skill is higher with the proportion of teachers who have the competence of the base of ICT as much as 62,96 \%. Around $65,26 \%$ the teachers are well trained using ICT, and $74,88 \%$ the teacher used ICT for a learning process. Overall the students used the internet for learning and computer lab for study. The number of participants students who follow learning use ICT around $98,1 \%$ and all students joint the class computer.

The third groups are consisting of 1 schools with different character compared other group. This group utilise the television for learning (37 unit) with the availability of funds or cost for services ICT is high ( $>60$ million rupiah per years). The quality of teachers in ICT skill is higher where all the teachers have capability using ICT, and all the students use the internet connection and computer lab for study. although all students have participated in participating in learning based ICT, but the proportion of students who attended computer class is low as much as 36,45 \%. 
The fourth groups are consisting of 10 schools that the utilisation of television for learning with average as much as 4,3 a unit per school. The availability of funds or cost for services ICT is $\operatorname{low}(>13$ million rupiah per years). The quality of teachers in ICT skill is low with the proportion of teachers who have the competence of the base of ICT as group have been making use of the internet connection and computer laboratories for learning. The number of participants students using the internet is the lowest (26,37\%) that compared with the average number of students the following learning using ICT and 21,77\% students joint the class computer.

Tabel 3. School Characteristics on ICT utilization for education

\begin{tabular}{|c|c|c|c|c|c|c|c|c|}
\hline \multirow{2}{*}{\multicolumn{2}{|c|}{ Indicator }} & \multicolumn{6}{|c|}{ SOM Clustering } & \multirow{2}{*}{$\begin{array}{l}\text { p-value } \\
<0,05\end{array}$} \\
\hline & & $\begin{array}{c}\text { Group } 1 \\
(n=11)\end{array}$ & $\begin{array}{c}\text { Group } 2 \\
(n=15)\end{array}$ & $\begin{array}{c}\text { Group } 3 \\
(n=1)\end{array}$ & $\begin{array}{c}\text { Group } 4 \\
(n=10)\end{array}$ & $\begin{array}{c}\text { Group } 5 \\
(n=5)\end{array}$ & $\begin{array}{c}\text { Group } 6 \\
(n=8)\end{array}$ & \\
\hline \multicolumn{9}{|c|}{ Infrastructure } \\
\hline ED2 & Utilization TV for a learning process & 2,27 & 4 & 37 & 4,3 & 3,8 & 1,88 & $1,00 \mathrm{E}-06$ \\
\hline \multicolumn{9}{|c|}{ Teacher Development } \\
\hline ED8 & Teacher who have ICT qualification (\%) & 83,68 & 62,96 & 100 & 47,03 & 25,42 & 29,04 & 0,0205 \\
\hline ED34 & $\begin{array}{l}\text { The availability service for supporting ICT } \\
\text { aan layanan pendukung TIK Sekolah }\end{array}$ & $\begin{array}{c}9,08, \mathrm{E}+0 \\
7\end{array}$ & $\begin{array}{l}1,25, \mathrm{E}+0 \\
7\end{array}$ & $\begin{array}{l}6,00, \mathrm{E}+0 \\
7\end{array}$ & $\begin{array}{l}1,32, \mathrm{E}+0 \\
7\end{array}$ & $\begin{array}{c}2,46, \mathrm{E}+0 \\
7\end{array}$ & $\begin{array}{l}3,03, \mathrm{E}+0 \\
7\end{array}$ & 0,0002 \\
\hline ED37 & $\begin{array}{l}\text { The proportion of teacher teach using ICT } \\
\text { facility (\%) }\end{array}$ & 80,53 & 74,88 & 100 & 73,73 & 70,11 & 29,17 & 0,0197 \\
\hline ED38 & $\begin{array}{l}\text { The proportion of expert teacher teach using } \\
\text { ICT facility (\%) }\end{array}$ & 74,9 & 65,26 & 100 & 70,09 & 44,7 & 15,38 & 0,0208 \\
\hline \multicolumn{9}{|c|}{ Utilization } \\
\hline ED6 & $\begin{array}{l}\text { The proportion of students has internet } \\
\text { access at school (\%) }\end{array}$ & 96,37 & 100 & 100 & 99,95 & 68,41 & 100 & $5,00 \mathrm{E}-07$ \\
\hline ED41 & $\begin{array}{l}\text { The proportion of students who have the } \\
\text { right to use computer laboratories at a school } \\
\text { to learning (\%) }\end{array}$ & 100 & 100 & 100 & 99,95 & 48,49 & 100 & $1,00 \mathrm{E}-11$ \\
\hline \multicolumn{9}{|c|}{ Student Participation } \\
\hline ED44 & $\begin{array}{l}\text { The proportion of students enrolled in the } \\
\text { classroom with based learning ICT (\%) }\end{array}$ & 95,52 & 98,1 & 100 & 76,71 & 89,29 & 26,37 & $1,00 \mathrm{E}-06$ \\
\hline ED45 & $\begin{array}{l}\text { The proportion of students who enrolled in a } \\
\text { classroom where skill computer basic taugh } \\
\mathrm{t}(\%)\end{array}$ & 88,02 & 100 & 36,45 & 57,6 & 50,26 & 21,77 & $9,00 \mathrm{E}-08$ \\
\hline
\end{tabular}

much as 47,03 \%. Around 70,09\% the teachers are well trained using ICT, and 73,73\% the teacher used ICT for a learning process. Around 99,95\% the students used the internet for learning and computer lab for study. The number of participants students who follow learning use ICT around $76,71 \%$ and $57,6 \%$ students joint the class computer.

The fifth groups are consisting of 5 schools that the utilisation of television for learning with average as much as 3,8 a unit per school. The availability of funds or cost for services ICT is high(> 24 million rupiah per years). The quality of teachers in ICT skill is low with the proportion of teachers who have the competence of the base of ICT as much as 25,42 \%. Around 44,7\% the teachers are well trained using ICT. It is contrary to the number proportion teacher using ICT as much as 70,11\%. This average show the lowest number school using ICT facility compared to other groups where the proportion of students utilize the internet and computer as much as $68,41 \%$ and $48,49 \%$. While the number of participants students who follow learning use ICT around 89,29\% and $50,26 \%$ students joint the class computer.

The last group are consisting of 8 schools that the utilisation of television for learning are lower (1,88 a unit per school). The availability of funds or cost for services ICT is higher(> 30 million rupiah per years). The quality of teachers in ICT skill is lower with the proportion of teachers who have the competence of the base of ICT as much as $29,17 \%$. Around $15,38 \%$ the teachers are well trained using ICT, and $29,17 \%$ the teacher used ICT for a learning process. It is opposed to the condition of the facility of the ICT in a school where all students in this

\section{Conclusion}

Research shows that SOM took place capable of being mapped out on the data ICT from 50 schools with 26 variables to become 6 clusters of with accuracy the value of quantisation error as much as 1,3831 and topographical error $0 \%$. The best group using and utilisation ICT for education is group number one and number two. Both of the group have higher prosentace each group which elements are teacher develop, participant and utilization students without influences of supporting service from ICT. However, the adverse or worst condition is group number six. This group is the lowest competence and quality of teacher using ICT; as a result, they give influence to students less to participants and interest learning using ICT and joint the class computer. Even though the schools have a supporter who services good enough and utilisation ICT.

The author believes that Pustekkom need cooperate to see this result for mapping location and cluster before applying the model ICT for Education. Group one and group two are better applying ICT for education using education television or mobile learning, but the group six, it is better for Pustekkom to taking action with training for teachers. Research has limitations in the methods of the sample collection, data collection, and the number of clusters. The author suggested that developed a method of the number of clusters, variety and expansion of the research and the collection and analysis of data in online.

\section{Daftar Pustaka}


Amin, M., 2012, Pengelompokan Potensi Daerah di Bidang Komunikasi dan Informatika Menggunakan Principal Component Analysis dan Self Organizing Map, Jurnal Penelitian Komunikasi, Informatika dan Media Massa, pp.169-176.

Agusta, Y., 2007, K-Means - Penerapan, Permasalahan dan Metode Terkait, Jurnal Sistem dan Informatika 3, pp.47-60.

Aokia, H., Kim, J., dan Lee, W., 2013, Propagation \& level: Factors influencing in the ICT composite index at the school level, Computers \& Education 60, 310-324.

Arti,Y., Faiza, NN., Wardhani, SS., Nugroho, AS., Handoko,D., Saifullah, Z., Ruswendi, W., Santoso, E., 2010, Mapping of Information and Communication Technology (ICT) progress using Self Organizing Map (SOM). Proceedings - 2010 2nd International Conference on Advances in Computing, Control and Telecommunication Technologies, ACT 2010, pp.185-187.

Azadnia, A.H., Saman, MZM., Wong, KY., Ghadimi, P., Zakuan, N., 2012, Sustainable Supplier Selection based on Self-organizing Map Neural Network and Multi Criteria Decision Making Approaches, Procedia - Social and Behavioral Sciences, 65(ICIBSoS), pp.879-884.

Brun, M., Sima, C., Hua, J., Lowey, J., Carrol, B., Suh., E., Daugherty, ER., 2007, Model-based Evaluation of Clustering Validation Measures, Pattern Recognition 40, pp. 807-824.

Budayan, C., Dikmen, I., Birgonul, MT., 2009, Comparing The Performance of Traditional Cluster Analysis, Self-Organizing Maps and Fuzzy C-Means Method for Strategic Grouping, Expert Systems with Applications 36, pp. 11772-11781.

Dharmaraj, S., Hossain, MA., Zhari, S., Harn, GL., Ismail, Z., 2006, The Use of Principal Component Analysis and Self-Organizing Map to Monitor Inhibition of Calcium Oxalate Crystal Growth by Orthosiphon Stamineus Extract, Chemometrics and Intelligent Laboratory Systems 81, pp. 21 - 28.

Diah Wulandari, Toni P., V. Gunawan, 2016, Penerapan Principal Component Analysis untuk Mereduksi Dimensi Data Penerapan Teknologi Informasi dan Komunikasi untuk Pendidikan di Sekolah , JSINBIS Vol 6 No. 2, 2016,pp. 91-96.

Dragomir, O.E., Dragomir, F., Radulescu, M., 2014, Matlab Application of Kohonen Self- Organizing Map to Classify Consumers' Load Profiles, Procedia Computer Science 31, pp.474 - 479.

Farjo, J., Assi, RA., Masri, W., Zaraket, F., 2013, Does Principal Component Analysis Improve Cluster-Based Analysis?, IEEE Sixth International Conference on Software Testing, Verification and Validation Workshops 52, pp. 400-403.

Hussain, A.J., Morgan, S. \& Al-Jumeily, D., 2011. How does ICT affect teachings and learning within school education. Proceedings 4th International Conference on Developments in eSystems Engineering, DeSE 2011, pp.250-254.

Gunter, S., Bunke, H., 2003, Validation Indices for Graph Clustering, Pattern Recognition Letters (24), pp. 1107-1113.

International Telecommunication Union, 2010, Core ICT Indicator, Switzerland.

Juntunen, P., Liukkonan, M., Lehtola, M., Hiltunan, Y., 2013. Cluster Analysis by Self-Organizing Maps: An Application to The Modelling of Water Quality In A Treatment Process. Applied Soft Computing Journal, 13(7), pp.3191-3196.

Kemendikbud, 2013. Peraturan Menteri Pendidikan dan Kebudayaan No. 99 Tahun 2013 tentang Tata Kelola Teknologi Informasi dan Komunikasi di Lingkungan Kemdikbud, pp.1-4.

Kohonen, T., 2013, Essentials of the self-organizing map, Neural Networks 37, pp.52-65.

López Iturriaga, F.J. \& Pastor Sanz, I., 2013. Self-organizing maps as a tool to compare financial macroeconomic imbalances: The European, Spanish and German case. Spanish Review of Financial Economics, 11(2), pp.69-84.

Mangiameli, P., Chen, S.K. \& West, D., 1996. A comparison of SOM neural network and hierarchical clustering methods. European Journal of Operational Research, 93, pp.402-417.

Matharage, S., Alahakoon, O., Alahakoon, D., Kapurubandara, S., Nayyar, R., Mukherji, M., Jagadish, U., Yim, S., Alahakoon, I.., 2011. Analysing Stillbirth Data Using Dynamic Self Organizing Maps. 2011 22nd International Workshop on Database and Expert Systems Applications, pp.86-90.

Mojarab, M., Memarian, H., Zare, M., Hossein Morshedy, A., H.Pishahang, M., 2014. Modeling of the seismotectonic provinces of Iran using the self-organizing map algorithm

Computers and Geosciences, 67, pp.150-162.
Pustekkom, renstra-pustekkom-kemendikbud-2015-2019, access: https://pustekkom.kemdikbud.go.id/renstra-pustekkomkemendikbud-2015-2019/

Pustekkom, Lakip Pustekkom 2017, access: http://pustekkom.kemdikbud.go.id/inc/uploads/2018/05/LAKIP2017_29012018_Digital-1.pdf

Pinheiro, M.M \& Simoes, D., 2012. Constructing Knowledge: An Experience of Active and Collaborative Learning in ICT Classrooms. TOJET, 11 pp.382-389.

Prasetyo, Eko, 2012, Data Mining: Konsep dan Aplikasi menggunakan MATLAB, Penerbit Andi, Yogyakarta.

Rendón, E., Abundez, I., Arizmendi, A., dan Quiroz, EM., 2011, Internal versus External cluster validation indexes, International Journal of Computers and Communications 5, pp. 27-34.

Sánchez, J., Salinas, Á. \& Harris, J., 2011. Education with ICT in South Korea and Chile. International Journal of Educational Development, 31, pp.126-148.

Schilithz, A.O.C., Kale,PL., Gama, SGN., Nobre, FF., 2014. Risk Groups in Children Under Six Months of Age Using SelfOrganizing Maps. Computer Methods and Programs in Biomedicine, 115(1), pp.1-10.

Shlens, J., A Tutorial on Principal Component Analysis, 2014, Google Research

UNESCO Institute for Statistics (UIS), 2009. Guide to Measuring Information and Communication Technologies (ICT) in Education, Canada.

UNESCO Institute for Statistics (UIS), 2014. ICT in Education in ASIA : A comparative analysis of ICT integration and $e$ - readiness in schools across Asia, Canada.

Umar, I.N \& Yusoff, M.T.M, 2014. A Study on Malaysian teacher's level of ICT skills and practices, and its impact on teaching and learning, Procedia - Social and Behavioral Sciences, 116, pp. 979-984.

Valcarel, A.G, Basilotta, V. \& Salamanca, C.L., 2014. ICT in Collaborative Learning in the Classrooms of Primary and Secondary Education, Comunicar- Media Education Research Journal,42 pp. 65-74. 